\title{
Objectifying thematic, spatial and temporal aspects of vegetation mapping for monitoring
}

\author{
M. E. Sanders ${ }^{1}$, G. M. Dirkse and P. A. Slim \\ Alterra, Green World Research, Wageningen University and Research Centre, Droevendaalsesteeg 3, \\ P.O. Box 47, NL-6700 AA Wageningen, the Netherlands \\ ${ }^{1}$ Corresponding author.E-mail: marlies.sanders@wur.nl
}

Keywords: Accuracy, Objectivity, Permanent plots, Plant species, Remote sensing, Sampling design, Sequential maps, Vegetation mapping.

\begin{abstract}
Ad hoc decisions during fieldwork reduce the accuracy and reliability of vegetation maps. A method is proposed to objectify vegetation (thematic aspects) mapping (spatial aspects) for monitoring (temporal aspects). The most accurate and reliable description of the vegetation is a list of all plant species found within a plot. Therefore, the proposed method is an interpolation of a spatially representative sample of permanent plots combined with aerial photo interpretation. The method is objective because surveyors do not have to make decisions during fieldwork based on their personal judgement. Moreover, it is flexible, because the classification and interpolation methods can be adapted to specific views or needs depending on the aim of a study.
\end{abstract}

The method was applied to an area in the north of the Netherlands in 1998. A sampling design with a density of 1 plot/ha was used, and interpolated with a perpendicular bisector. In 2002, the number of plots/ha was doubled. The influence of sample density on the mapping results was studied because it is an important decision to be made before fieldwork. Two plots/ha seem to be sufficient in order to obtain reliable information on patterns of plant species composition and vegetation types of the area, and their change over time. However, in patches where vegetation varies on a very small spatial scale this plot density was insufficient.

Abbreviations: DGPS-Differential Global Positioning System, GIS-Geographical Information System.

Nomenclature follows: Van der Meijden (1996).

\section{Introduction}

Vegetation monitoring is used to assess changes in vegetation. The aim of monitoring is usually related to the detection of effects of environmental changes, or to evaluate conservation or management strategies. Examples are the influence of soil subsidence as a result of gas extraction on the vegetation on the island of Ameland in the Netherlands (De Vlas and Marquenie 2003), vegetation succession in dunes (Van Dorp et al. 1985) or effects of nature management by grazing and cutting (Bakker 1989).

A common method to monitor species composition is to study vegetation in permanent plots (Kuechler and Zonneveld 1988). A permanent plot is an area of a limited size (for example $4 \mathrm{~m}^{2}$ ) where the vegetation is described at certain time intervals by making a list of plant species and estimating their cover. Permanent plots describe the changes in plant species composition accurately. It is considered most efficient to choose the location of the plots on the basis of prior knowledge of the direction and scale of the expected changes (Kuechler and Zonneveld 1988). A disadvantage of permanent plots is their limited area (usually a few square meters); therefore they may not be spatially representative for the entire terrain. Moreover, the plots can only be located at representative sites, the first time they are recorded. In the course of time vegetation will change and these sites may lose their representativity.

A common method to obtain vegetation information covering the entire terrain is mapping. Vegetation mapping comprises delineation, often supported by aerial photo-interpretation, of pre-defined plant communities that are described by vegetation plots or relevés (Kuechler and Zonneveld 1988). In this study, the plant communities of a local, national or any other classification system are called vegetation types. It is more efficient to map vegetation types than to map separate plant species because there are usually hundreds of species. Common aims are the detection of vegetation patterns and the estimation of the area covered by various vegetation types. Nature management organisations use vegetation maps to 
plan and evaluate their management (Bakker 1979, Schouten and van Ool 2003).

Many studies use sequential maps for monitoring (Londo 1974, Van Dorp et al. 1985, Janssen 2001) although their utility is poor since there are various causes for uncertainty (Kuechler and Zonneveld 1988, Goldsmith 1991, Janssen 2001). The vegetation types, discerned over time in sequential maps, are often incomparable and the boundaries may shift between maps due to inaccuracies. Moreover, the species composition of a vegetation type may vary from place to place and overlap with other types. This makes it difficult for a surveyor to recognise and delineate types in the field. It may lead to interpretation differences between surveyors, especially in gradients where boundaries have to be drawn according to personal judgement. Sometimes, the number and definition of vegetation types have to be adapted during fieldwork because a vegetation stand does not fit a pre-defined type; or aggregated types or transition types have to be delineated. Recognition of vegetation types in the field and delineation of these patterns become dependent on the experience and the knowledge of the surveyor, and are thus subjective. These interpretation differences cause inaccuracies when vegetation changes have to be identified and quantified with sequential maps. Several studies have tried to handle this subjectivity. A solution might be to use the old boundaries of a previous map (Janssen 2001), fuzzy logic (Droesen 1999) or to apply a grid comparison (Bakker and Ruyter 1981, Van Dorp et al. 1985). However, we believe that vegetation maps made by delineation of vegetation types in the field are imprecise, inaccurate and too subjective to monitor changes in plant species composition and vegetation.

\section{Aim}

The main question is how can vegetation mapping and monitoring be objectified but still be kept flexible? Objective means determined without the influence of one's judgement or intuition. Decisions made during fieldwork, which may lead to differences in judgement, should be minimised. All decisions to be made before fieldwork should be clear, well defined and well founded because it is impossible to go back in time to collect additional field data. A consequence of objectivity is that all steps in the method are determined and fixed. However, the method should also be flexible to be generally applicable. This means that the method can be adapted to different and changing circumstances, monitoring aims and purposes. Flexibility is an advantage in the long term because ecological issues, classification systems, expert views, technology and techniques may change. In conclusion: data collection should be objectified as much as possible, and classification to vegetation types or presentation in tables or maps should be flexible.

The basic assumption and starting point of this study is declared in two theses.

(1) The basic data of plant species composition collected in the field will remain interpretable for a very long period of time, while vegetation types will be outdated within decades (Dirkse 1998). Plant species are usually well defined in floras.

(2) The basic geometrical data collected by remote sensing will remain interpretable for a very long time, while boundaries mapped in the field will not.

A consequence of these theses is that fieldwork should neither concentrate on drawing boundaries nor on identifying vegetation types. It should concentrate on the elementary units of the vegetation, which are the plant species. In that case, the classification of species composition to a vegetation type and the delineation of differences in species composition become 'desk work' afterwards depending on the aim of mapping. It should be stressed at this point that processing of the field data can have at least two different aims, namely mapping (i.e., producing a map that is a representation of the terrain's vegetation), or monitoring (i.e., detecting the changes in the vegetation and its spatial pattern). Usually, these aims are combined by using sequential mapping as a tool to monitor vegetation. In our method, monitoring is even possible without making any map, thus avoiding the inaccuracies that are inevitable in the process of mapping.

This study comprises:

- A description of a method for objectifying vegetation mapping and monitoring.

- An application of the method to an area in the Netherlands.

- A demonstration of the objectivity of the method.

- A demonstration of the flexibility of the method.

\section{Proposed method}

A common method to monitor species composition is permanent plots, and a common method to delineate vegetation boundaries is image interpretation and interpolation of point samples (Kuechler and Zonneveld 1988, Van Holst 1990). Therefore, the proposed method is an interpolation of a spatially representative sample of permanent plots combined with aerial photo interpretation. Spatially representative refers to a sample design fit to 
map spatial patterns in the vegetation. This approach corresponds to the mathematical-statistical orientation described by Mueller-Dombois and Ellenberg (1974) and to the continuum concept of Curtis and McIntosh (1951). New is to use a spatially representative sample design of permanent plots for monitoring and mapping of both species composition and vegetation types.

In our method, the following steps are distinguished: I. Preparation: take spatially representative sample points.

Decision 1: choice of sampling design (i.e., the method to determine the location of the plots).

Decision 2: choice of sample density (i.e., the number of plots/ha).

\section{Decision 3: choice of plot size and shape.}

II. Fieldwork: locate plots with DGPS, make a list of all plant species and estimate their cover by eye.

III. Classify species composition per plot to a vegetation type.

\section{Decision 4: choice of classification method.}

IV. Interpolate points (plot location) to polygons, combine the interpolation with a remote sensing interpretation in GIS.

Decision 5: choice of interpolation method.

V. Repeat step I to IV several years later to monitor the changes.

Decision 6: choice of rotation scheme (i.e., the 'turnover' of the plots over time).

Steps I and II should be objectified as much as possible. Steps III, IV and V should be flexible so they can be adapted to the aim of the study or the specific views of the surveyor. The decisions we made are described below using a case study in the Netherlands.

\section{Application of the method in a study area}

The method was applied to two grasslands in the Lauwersmeer area. The Lauwersmeer is a nature reserve of 4617 ha in the North of the Netherlands which used to be an inlet of the Wadden Sea. The present lake was dammed off from the Wadden Sea in 1969 and the former tidal sand flats became colonized by vegetation. At this moment, most of the area is open water, forest or grazed rough grassland. Small parts are species rich grasslands that are mown once a year. Two of them, ca. 53 ha (De Lasten 30 ha and "het landje van Juffrouw Alie" 23 ha), were surveyed for this study in 1998 and in 2002. To save space, the figures presented to illustrate the method only pertain to "het landje van Juffrouw Alie" abbreviated as Juf.Alie.

\section{Preparation}

The first three decisions we had to make were about sampling method, sample density, and plot size and shape. Plot size has been the subject of study for many years. In grasslands, plots of 1 to $16 \mathrm{~m}^{2}$ are commonly used (Kent and Coker 1992, Schaminée et al. 1995, Kuechler and Zonneveld 1988). We chose $4 \mathrm{~m}^{2}$ because it is roughly the largest area that can be viewed without disturbing the plot. Regarding the plot shape we chose a circle $(\mathrm{r}=1.13 \mathrm{~m})$ because the perimeter length is less compared to a square (less edge effects) and moreover only the centre point has to be measured with DGPS and stored in GIS instead of 4 corners or a direction of the sides.

A starting point to determine sample density can be the minimal mapping unit, which is considered to be 0.25 $\mathrm{cm}^{2}$ on a map. This minimal mapping unit directs the maximum point density. For a 1:10 000 map, the minimal mapping unit is $50 * 50 \mathrm{~m}^{2}$, which results in a sample density of 4 points/ha (Van Holst 1990). However, such a high density is only efficient when the vegetation is highly variable. We chose a sample density $1 \mathrm{plot} / \mathrm{ha}$ in 1998 to begin with, and made sample density a subject of study. In 2002, we chose 2 points/ha: the old sample set of 1998, and a new sample set. The new sample set is made with the same sample method as in 1998. From these two sets, it is possible to study the influence of sample density.

As a sampling method we used a stratified systematic unaligned design. According to Smartt and Grainger (1974) and Oude Voshaar (1981), this sampling design estimates areas of mosaics of vegetation types slightly, but significantly more efficiently than random, stratified random or systematic sample designs. The stratified systematic unaligned sample comprises both a systematic and a random element. Stratification is on the basis of a regular grid, i.e. without prior knowledge of the study area. The grid cells are $100 * 100 \mathrm{~m}^{2}$, and each grid cell contains one plot. All plots in the first row get a random $\mathrm{Y}$ co-ordinate and all plots in the first column get a random X co-ordinate relative to its cell's sides. All other plots get their co-ordinates relative to their cell's sides from the first row and column (Fig. 1).

\section{Fieldwork}

The exact location of the plot must be marked in the terrain. An accuracy of several meters reached with a 


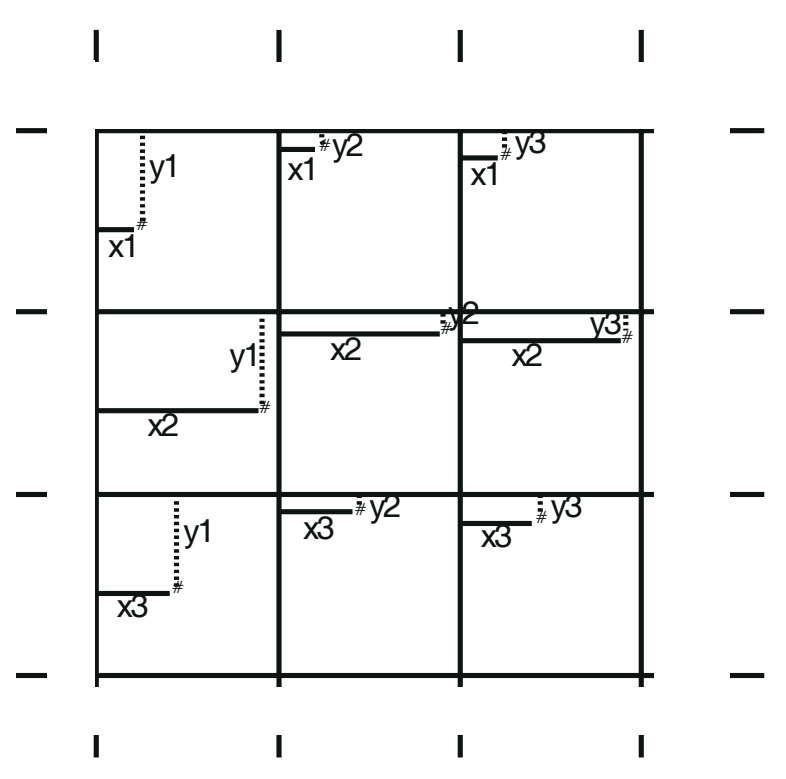

Figure 1. Location of the vegetation plots according to an unaligned systematic sample design. The figure shows a sub area of nine $100 * 100 \mathrm{~m}^{2}$ cells. The plots inherit their coordinates relative to their cell sides from the first row and column. The length of the lines in the cells, indicate the same distance to the cell sides to illustrate this inheritance (after Smartt and Grainger 1974).

handhold GPS is insufficient, because species composition may vary considerably on a scale of meters. Therefore, we used a DGPS, which has an accuracy of one centimetre. An advantage of this method is that the plot does not have to be marked permanently to relocate it later.

In the plot all plant species in all states have to be identified. In reality, two or more species (often rare or small vegetative plants) per plot are overlooked (Lepš and Hadincova 1992, Janssen 2001). Nilsson (1992) advises to increase accuracy by having two botanists analyse each plot independently. In our study, two experienced surveyors collected the field data, although not independently. They made a plant species list of every plot, estimated by eye the cover of each species (Dirkse 1998).

\section{Classify species composition per plot to a vegetation type}

The species composition of the plots was classified by using the program TWINSPAN (Hill 1979), a dichotomised ordination analysis. We decided to use TWINSPAN, but it is possible to use any other classification method. This classification is unsupervised, i.e., the rules for subdivision of the data set search for natural breaks in the species composition of the plots. The significance of the classes made by TWINSPAN was evaluated by expert judgement and the classes were assigned an indicative class name. The resulting vegetation classification system is only valid within the mapped area and represents the local variation in the vegetation (Dirkse 1998). The area of the vegetation types was calculated from the number of plots per type assuming that a plot is representative for 1 ha. This emphasises the importance to study the influence of sample density.

\section{Interpolate plot locations to polygons, combine with remote sensing in GIS}

The available photographs were black and white panchromatic and were taken in 1995 . They were scanned, georeferenced and resampled to an image of pixels with 2 $\mathrm{m}$ resolution and a geometric accuracy of less than one pixel. The aerial photos showed only gradual transitions in the vegetation, except for forest and former tidal stream channels. These former channels were identified and interpreted semi-automatically on the image (Fig. 2). The boundaries were checked in the field.

The gradual transitions were mapped by interpolating the sample points with a perpendicular bisector. The resulting map units are called Thiessen-polygons (see boundaries of Fig. 5). In this way, the best information about an unvisited point can be gleaned from the data point nearest to it (Burrough 1986). According to Burrough (1986), Thiessen-polygons are probably best for qualitative (nominal) data from point patterns. We decided to use Thiessen-polygons, but it is possible to use any other desired interpolation method.

The resulting map of former stream channels was combined with the interpolated map. The hard boundaries from the image overrule the gradual variation represented by the Thiessen-polygons. The angular boundaries of the Thiessen-polygons were smoothed in order to increase the readability of the map and to facilitate its acceptance.

\section{Monitoring of the changes}

In 2002, all plots of 1998 were surveyed again (set 1), and a new set of sample plots was drawn, again using the stratified systematic unaligned design (set 2). Hence, in 1998 the sample density was 1 plot/ha and in 2002, 2 plots/ha. The Steinhaus coefficient (=complement of the Bray - Curtis index, Legendre and Legendre 1998, p. 265) was used to quantify the change in the vegetation. The Steinhaus coefficient measures the similarity between vegetation samples or sets of samples. It is an index based on the number of species both samples have in common and have not in common and weights the species according to their abundance. A frequency table of set 1 (1998) and set 1 (2002) 


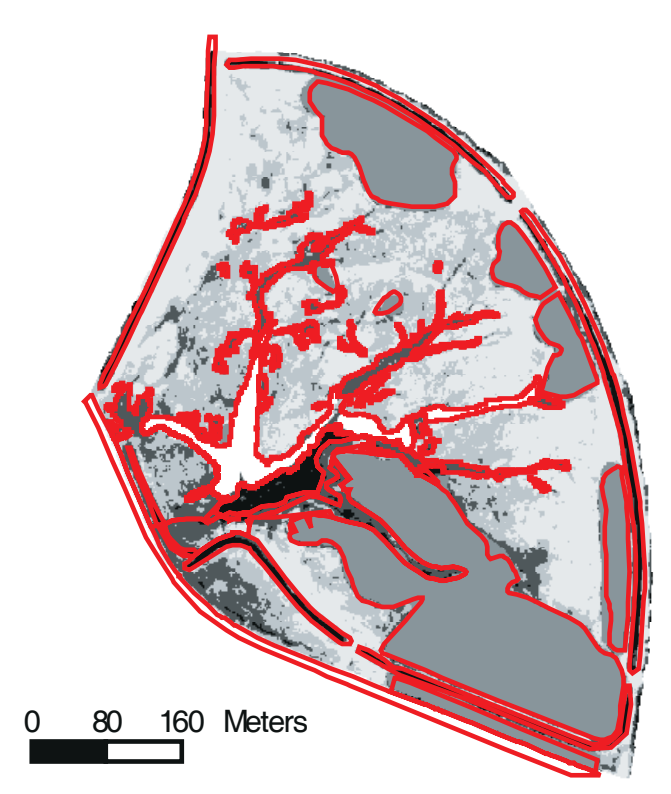

Figure 2. Image interpretation (red) on a scanned panchromatic aerial photograph of Juf.Alie.

was made and the Steinhaus coefficient between these sets was calculated.

Change detection can be applied to many variables of the plots, for example, which plant species appear or disappear from how many plots. The disappearance, appearance or cover change of indicative plant species tell an experienced plant ecologist what processes are active in the terrain. Furthermore, these processes can be revealed with indicator values (e.g., Ellenberg 1991) by analysing the change in average values per plot. Also, a biodiversity index, the 'evenness' (cf. Huston 1994) or simply the number of species per plot can be used to quantify local 'biodiversity' change. And finally, the change in vegetation types and patterns can be assessed. For this purpose the plots of 1998 were classified again in TWINSPAN, but now together with the 2002 plots. This may result in a different classification for the 1998 plots compared to the classification based on the 1998 plots only.

\section{Optimal density of sample points}

The influence of the sample density was analysed by a species approach and a vegetation pattern approach. The species approach is similar to the method that is sometimes used to determine plot size, which is by using a species-area curve (Cain 1938, Mueller-Dombois and Ellenberg 1974, Kent and Cooker 1992). The minimal plot size for sampling a plant community corresponds to the point at which the curve of species numbers against plot size levels off. In our case: the minimal sample size for sam- pling a terrain corresponds to the point at which the curve of the total species number vs. plot density levels off. Hence, we use the sample size instead of plot size on the $\mathrm{X}$-axis, and the total number of species instead of the number of species per plot on the Y-axis.

The vegetation approach is based on the assumption that the location of vegetation types should be stable. That is, a vegetation type at a certain location on the map should not disappear from the map when a single sample point is left out. In other words, every plot representing a certain type should have at least one neighbouring plot with the same type.

\section{Results}

\section{Vegetation map}

The vegetation map based on the TWINSPAN classification of the plots combined with remote sensing information is shown in Fig. 3. The boundaries based on the aerial photographs are sharp and presented as thin black lines on the map. The boundaries of the Thiessen-polygons represent gradual transitions in species composition and are presented as thick dashed grey lines on the map.

\section{Monitoring changes}

The plots made in 1998 were classified together with those made in 2002. We prefer a new classification from scratch above the one made in 1998 because extrapolation in space and time is always tricky. Table 1 shows the number of plots per vegetation type in 1998 (set 1) and in 2002 (set 1 and set 2), and it shows the changes in types

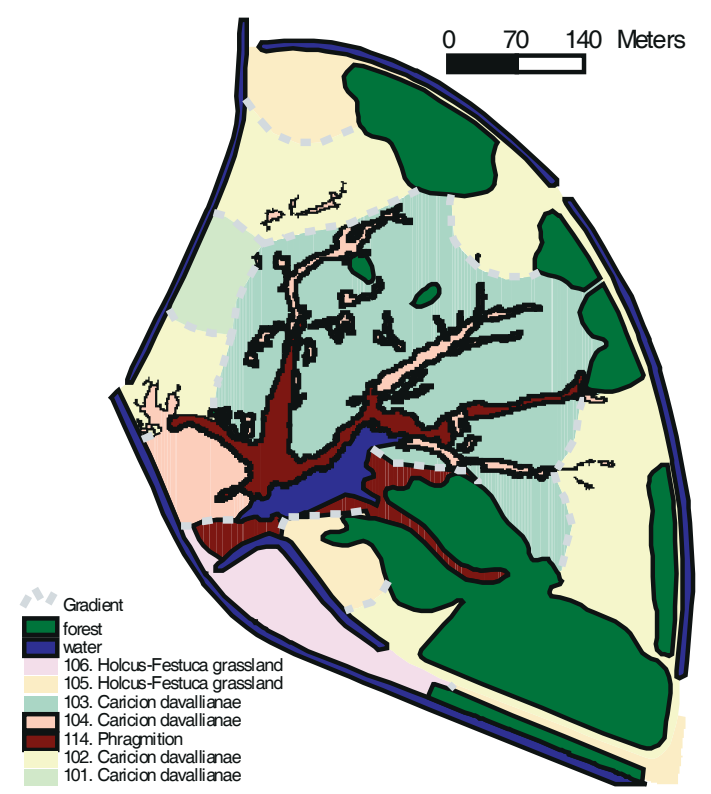

Figure 3. Vegetation map 1998 of Juf.Alie. 
between 1998 and 2002. The changes in vegetation are due to an increase of Calamagrostis epigejos, Holcus lanatus, Festuca rubra, Rhytidiadelphus squarrosus and Salix repens and a decrease in Parnassia palustris, Centaurium erythraea, Sagina procumbens and Dactylorhiza

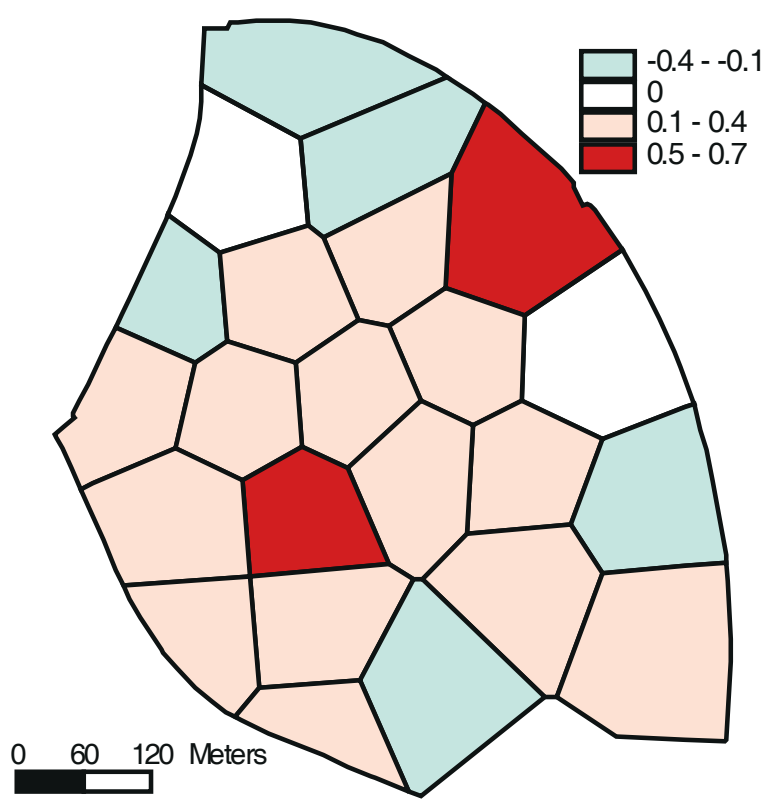

Figure 4. Change in Ellenberg acidity indicator value (Ellenberg 1991) between 1998 and 2002 of Juf. Alie. Polygons with acidification are red and polygons with the opposite process are green.

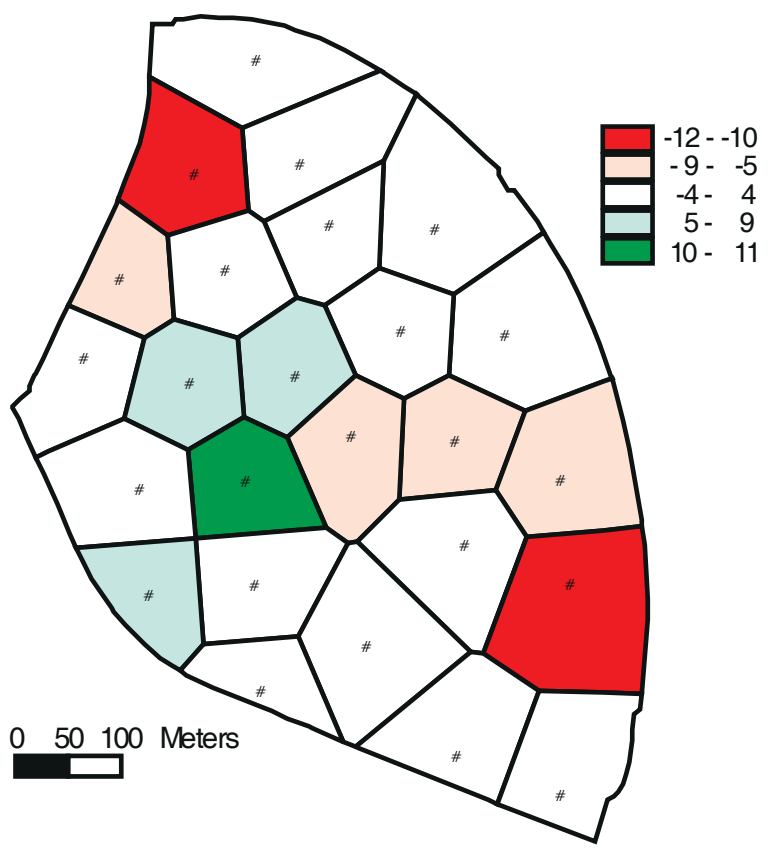

Figure 5. Increase (green) and decrease (red) in species number between 1998 and 2002 of Juf.Alie The symbols \# represent the plot locations. majalis. In ecological terms this can be interpreted as a gradual change of dune slack vegetation into grassland with tall forbs and scrub. The vegetation changes might be indicative for certain environmental changes. These changes can be assessed from the difference in average Ellenberg values per plot between the years. This is exem-

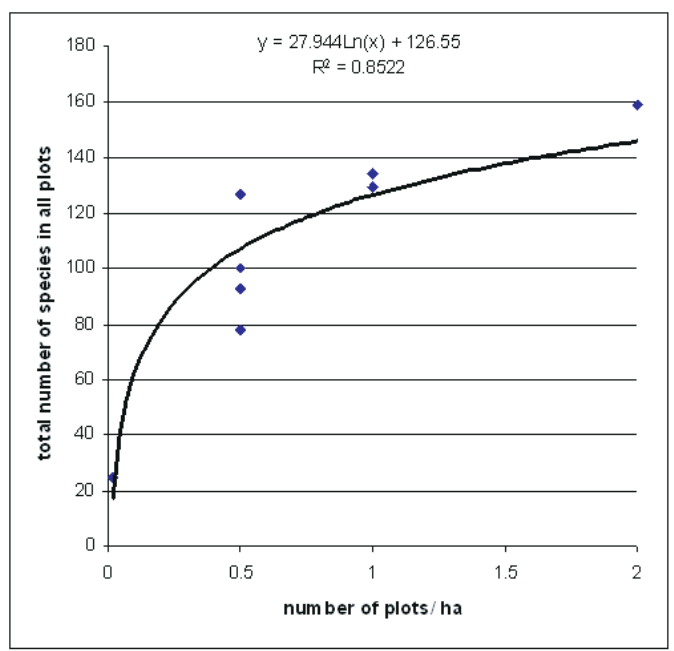

Figure 6. Species-sample density curve based on the 2002 data set. Fitted relationship: (total number of species) $=a_{0}+$ $\mathrm{a}_{1}[\log ($ number of plots/ha) . The smallest density is only one plot $(0.02$ plots/ha) which has on average 25 species. The density of $0.5 \mathrm{plots} / \mathrm{ha}$ is based on the even and odd numbers of set 1 and set 2 .

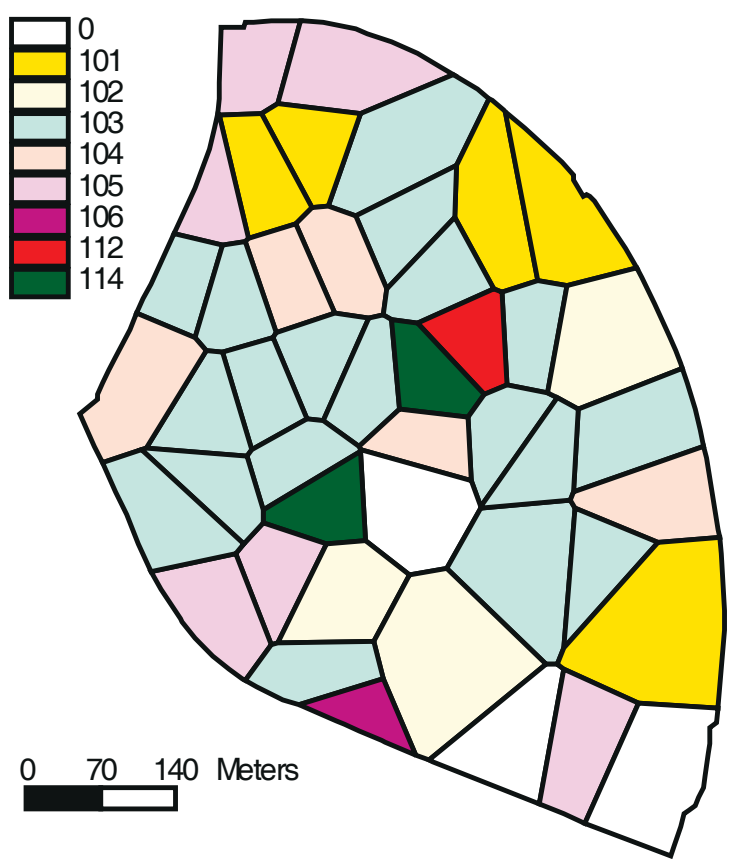

Figure 7. Pattern of vegetation types based on 2 plots/ha of Juf.Alie in 2002. The numbers correspond with the numbers in Table 1. A plot with at least one neighbour with the same type is assumed to ensure a stable pattern: a patch with a type will not disappear when one plot cancelled. 
Table 1. Number of plots per vegetation type in 1998 (column 3) and 2002(set 1 column 7 and set 2 column 8 ), the change in number of plots per type between 1998 and 2002 (column 4-6), the difference between sample sets 1 and 2 in 2002 (column 9), and the surface area estimated on the basis of the complete 2002 data set (column 10). The type nr. (column 2) are arbitrary, they link this table to Fig. 3 and 7.

\begin{tabular}{|c|c|c|c|c|c|c|c|c|c|}
\hline column number 1 & 2 & 3 & 4 & 5 & 6 & 7 & 8 & 9 & 10 \\
\hline & & no. plots & change & no. & & no. plots & no. plots & difference & area (ha) \\
\hline definition & type nr. & 1998set1 & 1998 & $\rightarrow$ & 2002 & 2002set1 & 2002 set2 & 2002 (set1-2) & 2002 \\
\hline $\begin{array}{l}\text { Caricion davallianae with Rhytidiadelphus } \\
\text { squarrosus \& Calamagrostis epigejos }\end{array}$ & 101 & 2 & & & & 3 & 2 & 1 & 2.5 \\
\hline $\begin{array}{l}\text { Caricion davallianae with Epipactis } \\
\text { palustris \& Parnassia palustris \& Linum } \\
\text { catharticum }\end{array}$ & 102 & 4 & & & & 3 & 0 & 3 & 1.5 \\
\hline $\begin{array}{l}\text { Caricion davallianae with Salix repens \& } \\
\text { Carex oederi }\end{array}$ & 103 & 9 & & & & 8 & 11 & 3 & 9.5 \\
\hline $\begin{array}{l}\text { Caricion davallianae with Salix repens \& } \\
\text { Juncus gerardi }\end{array}$ & 104 & 4 & & & & 4 & 1 & 3 & 2.5 \\
\hline $\begin{array}{l}\text { Holcus lanatus - Festuca rubra grassland } \\
\text { with Rhytidiadelphus squarrosus \& Cirsium } \\
\text { anense }\end{array}$ & 105 & 1 & & & 1 & 2 & 3 & 1 & 2.5 \\
\hline $\begin{array}{l}\text { Holcus lanatus - Festuca rubra grassland } \\
\text { with Lotus corniculatus \& Bromus } \\
\text { hordeaceus }\end{array}$ & 106 & 3 & & & & 3 & 3 & 0 & 3 \\
\hline $\begin{array}{l}\text { Lolio-Cynosuretum with Salix repens \& } \\
\text { Leontodon saxatilis }\end{array}$ & 107 & 2 & & & & 2 & 3 & 1 & 2.5 \\
\hline $\begin{array}{l}\text { Lolio-Cynosuretum with Festuca rubra \& } \\
\text { Calliergonella cuspidata }\end{array}$ & 108 & 3 & & & & 4 & 3 & 1 & 3.5 \\
\hline $\begin{array}{l}\text { Lolio-Potentillion with Cynosurus cristatus } \\
\text { \& Festuca rubra }\end{array}$ & 109 & 7 & & & 1 & 1 & 3 & 2 & 2 \\
\hline $\begin{array}{l}\text { Lolio-Potentillion with Salix repens \& } \\
\text { Juncus gerardi }\end{array}$ & 110 & 8 & & & $\underline{2}$ & 9 & 10 & 1 & 9.5 \\
\hline $\begin{array}{l}\text { Lolio-Potentillion with Juncus gerardi \& } \\
\text { Odontites vernus }\end{array}$ & 111 & 6 & & & 3 & 9 & 8 & 1 & 8.5 \\
\hline $\begin{array}{l}\text { Lolio-Potentilion with Rumex crispus \& } \\
\text { Phragmites australis }\end{array}$ & 112 & 3 & & & 1 & 4 & 1 & 3 & 2.5 \\
\hline Phragmition with Eupatorium cannabinum & 113 & 3 & & & & 2 & 2 & 0 & 2 \\
\hline Phragmition with Cirsium palustre & 114 & 0 & & & 1 & 1 & 1 & 0 & 1 \\
\hline Scirpus maritimus vegetation & 115 & 0 & & & & 0 & 1 & 1 & 0.5 \\
\hline (1) & & 55 & & & & 55 & 52 & 21 & 53.5 \\
\hline
\end{tabular}

plified here by the change in average Ellenberg acidity indicator value (Fig. 4). The Ellenberg values indicate that two patches became more acid (red) and five patches on the edge of the study area became less acid.

The best estimate of the area per vegetation type is the number of plots per type $(1$ plot $=1$ ha). Table 1 also shows the difference in number of plots per vegetation type between set 1 and set 2 (column 9). In five vegetation types the difference between set 1 and set 2 is more than one plot. Both sets (column 7 and column 8) should estimate the area of the vegetation types independently. However, when there are only a few plots per vegetation type, the estimation becomes less accurate. Also, the total number of plots per set differs: 55 and 52, respectively. Hence, the estimate of the total mapped area is 55 and 52 ha, while the area is measured in GIS 53.3 ha. This difference is due to edge effects, because many cells of the sampling grid are only partly inside the study area. In fact, ca. 50 plots may actually be too few for a study site of 53.3 ha. The estimate of the total mapped area based on 2 points/ha approaches the GIS-area (53.5 ha, column 10 in Table 1).

Over the entire study area, the sequential data sets (set 1 in 1998 and 2002) have a similarity (Steinhaus coefficient) of $84.5 \%$. The change in species composition per plot was also determined. Table 2 shows a list of species that appeared in or disappeared from five or more plots. The dune slack species Dactylorhiza incarnata disappeared from most plots and the grassland species Agrostis stolonifera appeared in most plots. It is not efficient to discuss change patterns of all 160 species separately. Therefore, only a map of change in the number of species per plot was made (Fig. 5). The number of species seems to decrease on the edges of the study area, and to increase in the middle.

\section{Optimal density of sample points}

A species based approach was used to determine optimal plot density: the species-area curve (Fig. 6). In this 
Table 2. Change in species between 1998 and 2002

\begin{tabular}{ll}
\hline Decrease (-) and increase in number of plots with a certain species \\
\hline-13 & Dactylorhiza incarnata \\
-12 & Cerastium fontanum ssp. vulgare \\
-11 & Taraxacum species \\
-9 & Centaurium littorale \\
-8 & Brachythecium rutabulum; Festuca rubra \\
-7 & Sagina procumbens; Leontodon autumnalis \\
-6 & Carex oederi ssp. oederi \\
-5 & Parnassia palustris; Carex distans \\
5 & Lathyrus pratensis; Rumex crispus \\
6 & Mentha aquatica; Lotus corniculatus; Myosotis laxa \\
7 & Pseudoscleropodium purum; Poa trivialis \\
8 & Prunella vulgaris; Euphrasia stricta \\
9 & Trifolium fragiferum \\
10 & Linum catharticum \\
11 & Galium palustre; Rhytidiadelphus squarrosus \\
12 & Odontites vernus \\
17 & Agrostis stolonifera \\
\hline
\end{tabular}

Table 3. Number of neighbours with the same vegetation type per polygon in Juf.Alie.

\begin{tabular}{lcc}
\hline Neighbours with the same type & Number of polygons & Percentage \\
\hline $\mathbf{0}$ & 11 & 26 \\
$\mathbf{1}$ & 18 & 43 \\
$\mathbf{2}$ or more & 13 & 31 \\
\hline
\end{tabular}

study a log-linear species-area curve was assumed (cf. Fisher et al. 1943, Tokeshi 1993). The curve is expected to level off to approach a limit (namely, the total number of plant species present in the area) as total plot area increases. According to the curve, the number of species increases from an average of 100 to ca. 130 and 160 with an increasing plot density of $0.5,1$ and 2 plots/ha. This implies that on a log linear scale, the curve does not level off between those densities.

The similarity of the two spatially different data sets (set 1 and set 2 in 2002) measured as a Steinhaus coefficient is $88.6 \%$. There is only a small difference in total number of species between set 1 and set 2 (Fig. 6): 134 and 129 , respectively. However, the two sets have only 104 species in common. When the similarity is $100 \%$, set 2 is redundant compared to set 1 . At a sufficient sample density the similarity between the two sets should approach $100 \%$. We consider a similarity of $95 \%$ sufficient, which implies that $1 \mathrm{plot} / \mathrm{ha}$ is not sufficient. A sample density of 2 plots/ha would be better, however, on the basis of the present data it is not possible to decide whether 2 plots/ha are really sufficient.

The vegetation approach assumes that every plot with a certain vegetation type needs at least one neighbour with the same type to ensure a stable pattern when one plot is left out. The interpolated map with Thiessen-polygons (Fig. 7) was used to count the number of neighbours per polygon with the same vegetation type (Table 3 ). Most polygons (74\%) have one or more neighbouring polygons with the same type. The remaining $26 \%$ of the polygons have no neighbours with the same vegetation type and thus are vulnerable to cancellation of plots. These polygons are mostly found near the perimeter of the study area and in the former stream channels, i.e. in highly variable vegetation. Hence, 2 plots/ha are sufficient for most of the area, but in some parts a higher sample density is necessary.

\section{Discussion}

\section{Sampling design}

Mueller-Dombois and Ellenberg (1974) describe subjective versus objective selection of sample sites. The objective sampling design is meant to be representative for the terrain under study. In this design, any prior knowledge of the vegetation types is not relevant. The subjective selection of sample sites is meant to represent all variation in vegetation types in the terrain. In this design, one should select sample plots mainly to promote a conclusive recognition, description, definition and differentiation of vegetation types. Extensive prior knowledge of the study area and the vegetation classification system is essential. Lack of prior knowledge and gradual transitions between vegetation types make the selection of plot locations subjective, because before sampling, it would be impossible to judge whether individual vegetation stands are differ- 
ent or not (Kuechler and Zonneveld 1988). On the other hand, rare vegetation stands or plant species can be explicitly included in the subjective selection of sites. These types may be important or interesting because they have a special protection status, for example, nature target types or target species. The probability to hit rare species or types with a stratified systematic unaligned design is low. With a sample density of 1 point/ha, a type should cover at least ca. one ha. When the area of a vegetation type or the plot density is larger, the estimated cover of this type is more accurate. For most of the vegetation types, 2 plots/ha seem to be sufficient. Increasing overall sample density would require an extremely dense network of plots just to accurately estimate the area of rare types. This would disproportionally increase the number of plots in common types, which would make the method inefficient.

Kuechler and Zonneveld (1988) propose stratified random sampling on the basis of strata derived from aerial photo interpretation. Photo interpretation is rather objective when abrupt transitions in vegetation structure are present in the area, but subjective for gradual transitions. For that reason, the strata are not stable and undermine a design fit to estimate areas of mosaics of vegetation types. Instead of using photo interpretation beforehand, we add the interpretation afterwards to create a more readable and recognisable vegetation map. In the same sense, it is possible to add rare but important vegetation stands mapped separately during fieldwork, in a less objective way. While placing the sample plots and describing them, the terrain is systematically crossed, and rare types can be mapped in a separate GIS-layer. We therefore advise to build the vegetation map as a union of the following layers: the Thiessen-polygons from the stratified systematic unaligned design, the photo interpretation, and the separately mapped rare types.

\section{Spatial autocorrelation and interpolation}

For estimating the standard error of the mean of an area, samples should not be autocorrelated (Burrough 1987). Classical hypothesis testing makes the assumption that the observations are independent from one another, while this condition is not met by data that are autocorrelated through space (Fortin et al.1989). According to Fortin et al. (1989), any ecological phenomenon found at a sample point may have an influence on points located close by or even at some distance away. Therefore, we assume it is allowed to interpolate between plots to create a map. We did not measure the distance at which spatial autocorrelation occurs (the 'range'), and for vegetation this distance may strongly vary from site to site.
It is common practice in soil science to make a map by interpolating point samples (Van Holst 1990). A sampling design based on the mapping scale is used. The soil samples are described, classified according to a reference system, and the boundary of map units are made by interpolation based on field characteristics. Marsman and De Gruyter (1986) studied two sample methods (subjective and objective, i.e., random) and two methods of boundary delineation (subjective by using field characteristics and objective by using Thiessen-polygons) and their influence on map accuracy and readability. They conclude that soil maps with field delineation achieved a better quality and readability than soil maps with Thiessen-polygons. In our study, better readability of the angular boundaries of the Thiessen-polygons is achieved by smoothing them. A supplementary study to assess the quality of the map in relation to other mapping methods is still to be performed.

\section{Classification and mapping vegetation types}

Classification is in essence abstraction; that means to express reality by way of a limited number of diagnostic characteristics (Kuechler and Zonneveld 1988) and thus a loss of information. The plots are assigned to a vegetation type based on the presence of characteristic species. However, not all characteristic species are present in all plots that belong to a certain vegetation type. Hence, classification may introduce a large inaccuracy.

Cherrill and McClean (1999) demonstrate that the spatial agreement in pairwise comparison of vegetation maps from a study site in the UK made by six different surveyors was only $25 \%$. The agreement of all six maps was only $8 \%$ of the total study area. Spatial errors in positioning of boundaries occurred but were a relatively minor source of the differences between the maps. The majority of differences were due to classification errors. Types with similar species composition were frequently confused. This confusion of types counts in favour of classification to vegetation types after data collection by fieldwork. Also, according to Goldsmith (1991) vegetation types are not suitable for monitoring because species cannot be grouped into classes with clear boundaries. $\mathrm{He}$ suggests recording the abundance of individual species because this would be more precise than recording vegetation types. Van der Maarel et al. (1985) found that large uncertainties in species composition of a vegetation type hampered an accurate change detection.

The surveyors in the study of Cherrill and McClean (1999) also made relevés to obtain additional information on the mapped vegetation. The Steinhaus similarity between the species lists from pairs of surveys ranged from 19 to $64 \%$. The surveyors reported problems in mapping 
boundaries in transition zones, with mosaics within a mapping unit, and in distinguishing closely related vegetation types.

\section{Boundaries}

Sharp boundaries are often man-made for example (former) trails or differences in management. They may also be due to steep environmental transitions. Gradual transitions in vegetation often correspond to gradual transitions in environmental factors like soil and hydrology. Some transition zones are so gradual that there may, in fact, be no place where a boundary line is justified (Kuechler and Zonneveld 1988). Kuechler and Zonneveld suggest one to decide arbitrarily how much of an admixture may be tolerated in a type and draw the boundary accordingly. Surely, this may introduce a large inaccuracy. A solution lays in mapping different boundary classes. The boundaries on a map are represented as sharp lines while often they should be interpreted as gradients in the vegetation. Visualisation in a GIS provides many opportunities to illustrate differences in gradients, by using line thickness, colour, and intersection (Kuechler and Zonneveld 1988). In our study, we mapped sharp boundaries with thin black lines and gradients with grey thick dashed lines. However, GIS-analyses become complicated when such a map is combined with other maps.

A scale related problem is the mapping of mosaics of several types per unit without boundaries. Mosaics become a problem when comparing (sequential) maps for monitoring. It is impossible to determine which part of the mosaic has changed. Theoretically, all combinations are possible which may not have occurred in reality (Van Dorp et al. 1985). For an accurate comparison of (sequential) maps, mosaic mapping should be avoided. When using permanent plots for monitoring, vegetation mosaics are no problem.

\section{Conclusions}

Permanent plots in a spatially representative sampling design are suitable both to make a vegetation map and to perform an accurate monitoring of a terrain. The method avoids mapping problems such as the need to recognise poorly separated types in a consistent way, to draw boundaries in gradients, or to map mosaic types. Secondly, the method avoids monitoring problems such as the need to determine the exact change in species composition on the basis of (sometimes poorly defined) vegetation types.

Permanent plots in a spatially representative sampling design are an objective and flexible method. The data gathered by fieldwork are considered the basic data. Surveyors do not need to make subjective decisions during fieldwork based on their personal judgement, knowledge and intuition. The choices that are made (sample design, sample size and plot size) are well described, unambiguous and cannot be interpreted differently by other surveyors using the method. The classification and interpolation methods become a desk study after the field work and thus can be adapted to specific views or needs depending on the aim of the study. When ecological issues, classification systems, expert views, technology or techniques change, classification and interpolation can be adapted accordingly.

Acknowledgements. We thank Han van Dobben, Diana Prins, Anne Schmidt for their valuable comments and Jan Willems and Hans Boll of the State Forest Service for their hospitality at our study area.

\section{References}

Bakker, J.P. 1979. Vegetation science and nature conservation. In: M.J.A. Werger (ed.), The Study of Vegetation. Junk, Den Haag, the Netherlands.

Bakker, J.P. and J.C. Ruyter. 1981. Effects of five years of grazing on a salt-marsh vegetation. A study with sequential mapping. Vegetatio 44:81-100.

Bakker, J.P. 1989. Nature Management by Grazing and Cutting. Geobotany 14. Kluwer, Dordrecht, the Netherlands.

Burrough, P.A. 1986. Principals of Geographical Information Systems for Land Resources Assessment. Clarendon, Oxford.

Burrough, P.A. 1987. Spatial aspects of ecological data. In: R.H.G. Jongman, C.J.F. ter Braak and O.F.R. van Tongeren (eds.), Data Analysis in Community and Landscape Ecology. Pudoc, Wageningen, the Netherlands.

Cain, S.A. 1938. The species-area curve. Amer. Midland Nat 19:573-581.

Cherrill, A. and C. McClean.1999. Between-observer variation in the application of a standard method of habitat mapping by environmental consultants in the UK. J. Appl. Ecol. 36:989-1008.

Curtis, J.T. and R.P. McIntosh. 1951. An upland Forest continuum in the prairie-forest border region of Wisconsin. Ecology 32: 3:476-496.

De Vlas, J., and J.M. Marquenie. 2003. The Impact of Subsidence and Sea Level Rise in the Wadden Sea: Prediction and Field Verification. NAM, Assen, the Netherlands.

Dirkse, G.M. 1998. The validity of general purpose flora-based classification of vegetation. $\mathrm{PhD}$ thesis, University of Utrecht, the Netherlands.

Droesen, W.J. 1999. Spatial modelling and monitoring of natural landscapes: with cases in the Amsterdam Waterworks Dunes. $\mathrm{PhD}$ thesis, Wageningen Agricultural University, the Netherlands.

Ellenberg, H. 1991. Zeigerwerte der Gefäszpflanzen (ohne Rubus). Scripta Geobotanica 18:9-166.

Fisher, R, A.S. Corbet and C.B. Williams. 1943. The relation between the number of species and the number of individuals in a random sample from an animal population. J. Animal Ecol. 12:42-58. 
Fortin, M., P. Drapeau and P. Legendre. 1989. Spatial autocorrelation and sampling design in plant ecology. Vegetatio 83:209222.

Goldsmith, F.B. 1991. Monitoring for Conservation Ecology. Chapman and Hall, London.

Hill, M.O. 1979. TWINSPAN, A FORTRAN program for arranging multivariate data into an ordered two-way table by classification of the individuals and attributes. Cornell University, Ithaca.

Huston, M.A. 1994. Biological Diversity; The Coexistence of Species on Changing Landscapes. Cambridge University Press, Cambridge.

Janssen, J.A.M. 2001. Monitoring of salt-marsh vegetation by sequential mapping. $\mathrm{PhD}$ thesis, University of Amsterdam.

Kent, M. and P. Coker. 1992. Vegetation Description and Analysis, a Practical Approach. Wiley, Chichester.

Kuechler, A.W. and I.S. Zonneveld. 1988. Vegetation Mapping, Handbook of Vegetation Science, part 10. Kluwer, Dordrecht, the Netherlands.

Legendre, P. and L. Legendre. 1998. Numerical Ecology. Elsevier, Amsterdam.

Lepš, J. and V. Hadincova. 1992. How reliable are your vegetation analyses? J. Veg. Sci. 3:119-124.

Londo, G. 1974. Successive mapping of dune slack vegetation. Vegetatio 29:51-61.

Marsman B.A. and J.J. De Gruijter. 1986. Quality of soil maps. A comparison of survey methods in a sandy area. Soil Survey $\mathrm{Pa}-$ pers, no 15. Soil Survey Institute, Wageningen, the Netherlands.

Mueller-Dombois, D. and H. Ellenberg. 1974. Aims and Methods of Vegetation Ecology. Wiley, New York.

Nilsson, C. 1992. Increasing the reliability of vegetation analyses by using a team of two investigators. J. Veg. Sci. 3:565.
Oude Voshaar, J.H. 1981. Steekproefmethoden in het onderzoek naar verspreiding van perceelsvormen: oppervlakteschatting van mozaiken via steekproefpunten. IWIS-TNO, Wageningen, the Netherlands.

Schaminée, J.H.J., A.H.F. Stortelder and V. Westhoff. 1995. De vegetatie van Nederland. Deel 1. Inleiding tot de plantensociologie - grondslagen, methoden en toepassingen. Opulus, Leiden.

Schouten M. and M. van Ool. 2003. Werken met waarden bij Staatsbosbeheer. Natuurbehoud als beschavingsnorm. Jaarverslag Staatsbosbeheer 2002.

Smartt, P.F.M. and J.E.A. Grainger. 1974. Sampling for vegetation survey: some aspects of the behaviour of unrestricted, and stratified techniques. J. Biogeogr. 1:193-206.

Tokeshi, M. 1993. Species abundance patterns and community structure. Adv. Ecol. Res. 24:111-186.

Van Holst, A.F. 1990. Bodemkartering en bodemkaarten. In: H. de Bakker and W.P. Locher (eds), Bodemkunde van Nederland. Deel 2, bodemgeografie. Malmberg, Den Bosch, the Netherlands.

Van der Maarel, E., R Boot, D. van Dorp and J. Rijntjes. 1985. Vegetation succession on the dunes near Oostvoorne, the Netherlands; a comparison of the vegetation in 1959 and 1980. Vegetatio 58:137-187.

Van der Meijden, R., 1996. Heukels' Flora van Nederland. WoltersNoordhoff, Groningen, the Netherlands.

Van Dorp, D., R. Boot and E. van der Maarel. 1985. Vegetation succession on the dunes near Oostvoorne, the Netherlands, since 1934, interpreted from air photographs and vegetation maps. Vegetatio 58:123-136. 